\title{
ПСИХОЛОГІЧНА КУЛЬТУРА МАЙБУТНІХ МЕНЕДЖЕРІВ СФЕРИ ДОЗВІЛЛЯ: УПРАВЛІНСЬКІ ВМІННЯ
}

\section{Кот Галина Миколаӥвна \\ Кандидат психологічних наук, дочент, дочент кафедри психології Киїського національного університету культури $і$ мистеитв, м. Київ (Украӥна)}

\begin{abstract}
Анотація. Стаття присвячена системі психологічних управлінських вмінь, яка сприяє максимізації рівня розвитку менеджерської ефективності та формуванню психологічної культури майбутніх менеджерів сфери культури та дозвілля. Система психологічних управлінських вмінь - це інтегрована, цілісна особистісна конфігурація навичок реальної поведінки менеджера сфери культури та дозвілля. Професійно-значущі уміння та навички розглядаються як окрема шкала для виміру ступеня розвитку управлінської майстерності менеджера. Конструювання простору психологічних характеристик професійно-значущзих вмінь $i$ навичок, $i$ з його допомогою розробка психологічних механізмів підвищення ефективності керівництва сферою культури сприяє формуванню психологічної культури майбутніх менеджерів сфери дозвілля.
\end{abstract}

Ключові слова: психологічна культура, управлінські вміння, майбутні менеджери сфери дозвілля, управлінська ефективність.

Постановка проблеми. Сучасна психологічна наука пропонує для використання в сфері управління високоякісну, практичну інформацію з питань оптимізації управління i дуже широкий спектр репертуарів управлінської поведінки, які з успіхом використовуються менеджерами в економічній, політичній та інших сферах суспільного життя з метою підвищення ефективності досягнення організа- ційних цілей (наприклад, технології впливу, інтенсифікації розвитку особистості, формування колективів і команд, вирішення конфліктів, впровадження нововведень та інші). Разом 3 тим дуже повільно йде впровадження передових психолого-педагогічних технологій в практику сфери культури та дозвілля, що в першу чергу обумовлено недоліками в професійній підготовці, по-друге - внутрішнім чин- 
ником - відсутністю мотивації відповідного фахового зростання, по-трете - недостатньою методичною розробкою методів, прийомів i технології активного навчання менеджерів.

Як і будь-яка інша діяльність, управлінська діяльність характеризується різним рівнем іiї якісних параметрів, виконується з більшою або меншою ефективністю. Головними факторами її ефективності виступають управлінські вміння саме тому, що управлінська діяльність виступає багаторівневою та поліфункціональною. Роль менеджера не тільки віддавати розпорядження, карати чи винагороджувати, але й створювати сприятливий морально-психологічний клімат, вирішувати міжособистісні конфлікти, підтримувати своїх підлеглих. Менеджер стає організатором самостійної роботи підлеглих, об'єднаних у команди. Саме тому багато вчених працює над питанням важливих характеристик, які мають бути притаманні успішному менеджеру для ефективної та успішної професійної діяльності. Наш досвід проведення психологічних тренінгів та спілкування зі студентами, менеджерами сфери культури та дозвілля виявив надзвичайну їх зацікавленість в реальних управлінських вміннях, в формуванні реальної управлінської поведінки, яка веде організації до успіху. Ці спостереження - показник актуальності вивчення проблеми формування психологічної культури, тобто системи психологічних вмінь.

\section{Аналіз останніх досліджень і публі-} кацій. На індивідуальному рівні проблема психологічної культури управління ще не вивчалась, хоча в окремих аспектах і в зв'язку з іншими цілями виступала предметом спеціального вивчення в дослідженнях як зарубіжних (Р. Маслоу, Ф. Харцберг, Д. Мак-Грегор, Р. Болейк, Д. Мутон та ін.) так і вітчизняних вчених (Л. Н. Карамушка, О. Бондарчук Я. Л. Коломінський, Б. Д. Паригін, P. Х. Шакуров, Л. Г. Лаптєва, В. А. Сластьонін та ін.). Особистісний потенціал менеджерів розглядають у своїх роботах М. Вудкок, Д. Френсіс, Лі Якокка, Ф. Тейлор, А. Файоль [5, с.8].

Вивченням психологічного змісту поняття «самореалізація» та «професійна самореалізація» займалися Л. Карамушка, Л. Коростильова, С. Максименко, А. Маслоу, В. Осьодло , М. Ткалич, К. Роджерс та ін. Вивченням самовдосконалення та самореалізації особистості як ключової умови її професійного та життєвого успіху досліджували О. Бондарчук, Т. Говорун, С. Максименко та ін. $[6$, c. 4$]$.

Попередній семантичний аналіз проблеми змісту і структури психологічної культури менеджерів сфери культури та дозвілля виявив ведучі напрями в класифікації та розгляді характеристик ефективних менеджерів. В нашому дослідженні цільовим компонентом для максимізації рівня розвитку менеджерської ефективності виступає праксеологічний 
компонент - реальна ефективна управлінська поведінка менеджера, яка спирається на широкий репертуар умінь і навичок, заснованих на сучасних досягненнях психології.

Мета дослідження полягає в конструюванні простору психологічних характеристик професійно-значущих вмінь і навичок, і з його допомогою розробку психологічних механізмів підвищення ефективності керівництва сферою культури та дозвілля.

Виклад основного матеріалу і результатів дослідження.

Управлінська діяльність має три основних складових: 1) діяльність, що пов'язана 3 організаціс: та управлінням певною системою; 2) діяльність що пов'язана 3 управлінням людьми, міжособистісна взаємодія; 3) діяльність, що пов'язана безпосередньо з організацією технологічного процесу.

В залежності від того, наскільки вдало менеджер може забезпечити та узгодити між собою три складових і визначається ефективність управління.

Всі складові управлінської діяльності вимагають, крім наявності здібностей та професійних якостей менеджера, цілу систему професійно-значущих умінь та навичок, які забезпечують ефективну організацію управління людьми та досягнення поставлених цілей керівництва.

Дослідниця М. О. Ізмайлова, вважає, що професійні навички фахівця - це способи ефективного виконання професійної дії, дове- дені до автоматизму. До особливостей професійних навичок відносяться: точність дій, швидкість, економічність (виконання при мінімально можливих зусиллях і витратах енергіï), машинальність (виконання без концентрації уваги на техніці дій), стереотипність (однаковість виконання при повторах), консервативність (трудність зміни), надійність (протидія руйнівним факторам - перерв у виконанні, перешкод, негативним психічним станам рекламіста), успішність в досягненні потрібного результату [2;6].

За особливостями «внутрішньої схеми» управлінської діяльності, розрізняють наступні психологічні навички: сенсорні (спостереження, огляд, виявлення особливостей співрозмовника, розглядання дрібних деталей, їх ідентифікація, визначення відстані на око, температури шляхом дотику до предмета рукою, розрізнення запахів і інші), розумові (розробка звернення, робота 3 документами, їх оформлення і заповнення, читання електронної схеми, швидка оцінка обстановки, прийняття рішень, розрахунки, самоконтроль, дотримання норм і положень, планування та ін.), рухові (впевнене виконання рухових робочих рухів, володіння інструментом, маніпуляція управлінням транспортним засобом і т. п.) i комплексні (навички спілкування та психовізуальної діагностики, проведення психоаналізу документів, роботи на комп'ютері, організаційні, - освоєний професіоналом комплексний спосіб успішного виконання складної 
професійної дії або рішення задачі в нестандартних, незвичайних, ускладнених ситуаціях. Якщо навички забезпечують впевнені та ефективні дії в стандартних повторюваних ситуаціях, то вміння - саме в нестандартних, різноманітних ситуаціях, які помітно відрізняються одна від одної. Уміння менеджера виявляються у правильному визначенні своєрідності ситуації, яка виникла, прийнятті адекватного рішення, гнучкій зміні порядку і способу дій, осмисленому введенні в дію нових прийомів і способів, що відповідають реальним обставинам.

Професійно-значущі уміння та навички як психологічний чинник ефективного управління передбачає вищий рівень розвитку особистісної майстерності, що виявляється у граничному рівні автоматизованості ключових управлінських вмінь, заснованих на використанні психологічних знань і закономірностей, та спонтанна адаптивність в їх практичному застосуванні і легкій ситуативній модифікації. Професійна майстерність в діяльності менеджера сфери дозвілля - це ефективність виконання завдань професійної діяльності; майстерність створювати творчий продукт; майстерність працювати з клієнтом і досягати результату; легкість виконання складних завдань професійної діяльності.

Систему професійно-значущих умінь та навичок менеджера сфери дозвілля складають: комунікативні (вміння переконувати, аргументувати, зацікавлювати, вміння вести пе- реговори, домовлятися, колективне мислення як форма пошуку найкращого рішення в складній ситуації); управлінські вміння, уміння розробляти і створювати рекламний продукт (творчий компонент); організаційні вміння (уміння організовувати власну роботу і роботу інших). Важливість організаційного спрямування діяльності менеджера сфери дозвілля полягає у тому, що співробітник повинен швидко розібратися в ситуації, що склалася, виділити найсуттєвіші, головні ситуаційні фактори, прийняти найдоцільніше рішення. Зробити це без високої самоорганізованності і координації спільних зусиль дуже важко[6, c. 63-64].

Аналіз літератури з проблем менеджменту, теорії управління, популярної літератури, яка містить вислови і узагальнення щодо особливостей ефективних керівників, знань і навичок менеджерів, виявив існування значної кількості поглядів на проблему переліків та класифікацій вмінь $[2,3,4,7,9,10]$.

Кожне з перелічених вмінь ми розглядаємо як окрему шкалу для виміру ступеня управлінського розвитку менеджера, що формує вектори в багатовимірному просторі професійно-значущих вмінь. Інтенсивність вміння ми визначаємо наступними якісними характеристиками: найнижчій рівень - знання про вміння, без реальної здатності його реалізувати, далі рівні поступового покращення його виконання із зменшенням числа помилок, потім рівень автоматизованості вміння 
(мінімальне втручання свідомості подібно до вміння писати букви), вищий рівень характеризується майстерністю, легкістю реалізації та здатністю до вільної імпровізації і модифікації вміння.

За результатами вивчення літератури були відібрані судження про вміння менеджерів, які на семантичному рівні (гіпотетично) містять найбільшу психологічну компоненту. Наведену далі класифікацію слід вважати як таку, що відкрита для доповнення, умовною і не остаточною. Ми вважаємо, що психологічні вміння менеджерів існують як система, в якій компоненти за об'ємом пересікаються, спираються один на одного, породжують попарні, потрійні та вищого порядків системні ефекти взаємодій. Саме з причини системного характеру психологічних вмінь остаточну класифікацію буде виконано за прагматичними критеріями ефективності та значущості на основі обчислення системоутворюючих факторів.

\section{I. Психологічні технології взаємодій.}

До першої групи вмінь ми віднесли психологічні знання і вміння, що їм відповідають, пов'язані, насамперед, з діловим спілкуванням: вміння встановлювати контакт, привернути і захопити увагу, підтримати увагу, ставити питання, слухати, триматися норм ділового етикету у спілкуванні, спостерігати та використовувати невербальну поведінку, аргументувати, переконувати, контраргументувати, приводити партнера до прийняття рішень, проводити наради, вести дискусії та проводити різні типи ділових переговорів.

Друга технічна група психологічних навичок менеджерів поєднала компоненти, що розкривають потенціал керівництва - вміння впливати на людей: заохочувати, критикувати, віддавати накази, давати розпорядження, переконувати, навіювати, знижувати опір, вміння покарати, інструктувати, чітко ставити задачу, викликати довіру до себе, захопити та надихнути співробітників, делегувати повноваження, підтримувати дисципліну, розподіляти роботу, координувати дії співробітників, контролювати персонал і процес, мотивувати підлеглих.

Психологічні вміння, пов'язані 3 педагогічним аспектом управлінської діяльності: вміння навчати, приймати на роботу і вводити в курс справ, проводити атестацію і давати оцінку, консультувати підлеглих, надавати психологічну допомогу.

Третя - група психологічних вмінь, пов'язана із здатністю виступати публічно: здатність до ефективної самопрезентації, вміння гнучко вибирати оптимальну структуру публічного виступу, вміння враховувати особливості і реакції аудиторії, використовувати невербальні компоненти спілкування, використовувати експресію, проводити презентації та прес-конференції, вміння правильно реагувати і використовувати настрої аудиторії, вміння використовувати широкий репертуар риторичних засобів. 


\section{II. Психологічні технологї роботи 3} групами.

Група психологічних особливостей взаємодій менеджерів, що поєднує вміння в області групової роботи: вміння наладити взаємодії інших, формувати команду, формувати групові цінності, формувати команду однодумців, формувати колектив, розвивати ініціативу підлеглих, враховувати індивідуальні відмінності, відстоювати інтереси колективу, стимулювати групову самоорганізацію, стимулювати співробітників до відкритості, формувати атмосферу одночасно доброзичливості, відповідальності і вимогливості.

Група психологічних особливостей взаємодій менеджерів, що поєднує вміння в області управління стосунками: вміння підтримувати настрій, прогнозувати реакції інших, утримувати ініціативу у спілкуванні, утримувати правильний стиль і тон мови, встановлювати правильні відносини з рівними, підлеглими і керівництвом, протистояти тиску зверху, протистояти опору знизу, формувати позитивні відносини з усіма, формувати корисні для діла відносини, вміння викликати доброзичливість до себе.

Психологічні навички, пов'язані з вмінням вирішувати конфлікти: вміння попереджувати конфлікти, вирішувати виробничі конфлікти, вміння вирішувати міжособистісні конфлікти, вміння конструктивно (функціонально) використовувати конфлікти, вміння володіти собою в конфлікті, вміння домінувати в екстремальних умовах, вміння використовувати ідеї, протилежні своїм, вміння побачити себе в конфлікті зі сторони та с позиції співрозмовника.

\section{III. Внутрішні психологічні технологї.}

Група вмінь та навичок, пов'язаних 3 особистою ефективністю: вміння ставити цілі та планувати їх досягнення, використовувати логічні та інтуїтивні методи прийняття рішень, планувати свою діяльність, планувати діяльність підлеглих, вміння досягати результату, працювати без ресурсів, підтримувати стан постійного саморозвитку, вміння вирішувати проблеми, вміння підкоритися режиму, знаходити прості рішення складних проблем, ефективно використовувати час, виконувати роботу якісно, своєчасно закінчувати роботи, та здатністю керувати собою: вміння керувати функціональним станом, ефективно діяти в умовах стресу і обмеження часу, вміння керувати особистою життєвою ситуацією, вміння переборювати свої слабкості. Більшість 3 вимог до професійності менеджерів - це ефективна особистісна діяльність у стресових ситуація та під тиском щодо досягнення цілей управління. Навички самоконтролю, вміння опановувати себе пов'язане 3 дуже напруженим, емоційно інтенсивним процесом роботи, а також нерідкими стресами 3 різних причин, в тому числі, і через підвищену вимогливість клієнтів. Психологічна атмосфера, темп роботи і міжособистісні труднощі періодично породжують у менеджерів сфери дозвілля до- 
сить значний стресовий стан. Тi, хто не витримують, звільняються або за власним бажанням, або за наказом керівництва - в організації залишаються менеджери 3 підвищеним рівнем стресостійкості, здатністю опановувати себе[6, с.114-116].

Вміння менеджера, пов'язані з особистою етикою: здатність дотримуватись норм етики і моралі, правил етикету, правил і етики організації, вміння брати і нести відповідальність.

VI. Інтелектуальні та інформаційні технологї.

Група інтелектуальних вмінь окреслюється характеристиками мислення менеджера, які разом визначають його вміння мислити: цілісність, системність, структурність, аналітичність, раціональність, логічність, критичність, глибина, гнучкість, нестандартність, не стереотипність, тенденція до комбінування, образність, практичність, стратегічність, тенденція до упорядкування; та пов'язані з ним вміння працювати з інформацією: вміння оперувати великими об'ємами інформації, працювати з літературою та довідниками, обробляти інформацію, викладати ідеї письмово та правильно використовувати засоби комунікації.

Досвід підказує, що серед умінь в подібних наведеному переліках є ключові (на змістовному рівні ключові вміння за об'ємом мають найбільшу спільну 3 іншими частку, що емпірично виявляється як найбільша сума квадратів вектору коефіцієнтів кореляцій ключо- вого показника), які суттєво прискорюють розвиток загальної їх системи. Обрана нами модель дослідження спрямована саме на пошук головних компонент як інструментів інтенсифікації розвитку психологічної культури керівників.

Інтенсифікація процесу формування психологічної культури в підпросторі психологічних вмінь можлива шляхом першочергового розвитку ключових, з яких починається розвиток другорядних, підпорядкованих вмінь, і системооутворюючих - таких, що мають найбільшу спільну частку (на емпіричному рівні - спільну долю загальної дисперсіі) в групі змістовно близьких вмінь.

Взаємодія індивідуальних рис і досвіду особистості, управлінської ситуації, актуалізованих психологічних навичок поєднується в особливий конгломерат (патерн) своєрідних прийомів впливу, контакту, відношень менеджера до інших, що разом може бути визначено терміном «стиль». Менеджер сфери дозвілля як головний суб'єкт управлінської діяльності своєю індивідуальністю впливає на управлінський процес, визначає характер управління організацією, їі життєдіяльність. Поняття «стиль» (лат. - стержень, паличка для письма) - своєрідний управлінський почерк, сукупність методів і прийомів діяльності, поведінки, які використовує менеджер для досягнення поставленої мети, а також характер його взаємовідносин із підлеглими, з рівними за рангом колегами по роботі, вище призначе- 
ними керівниками. Коломінський Н. Л. визначає стиль управління як систему методів, прийомів, засобів, які переважають в управлінській діяльності керівника, а також особливості їх застосування, які обумовлені його особистістю $[4$, с. 78$]$.

Стиль керівника, як вказують дослідження вчених, не є вродженою якістю, а формується в процесі діяльності та змінюється, тобто підлягає корегуванню та розвитку. Стиль керівництва характеризує керівника як певну особистість, індивідуальність, суб'єкта діяльності, який $є$ «...інтегруючою, централізуючою, координуючою «інстанцією» діяльності. Він узгоджує всю систему своїх індивідних, психофізичних, психічних i, нарешті, особистісних можливостей, особливостей 3 умовами і вимогами діяльності не парціально, а цілісним образом» [3; 4; 7].

Проблема стилю важлива ще й тим, що стиль роботи менеджера формує і стиль роботи підлеглих, їх міжособистісного спілкування та спілкування з замовниками.

В контексті системної методології ми розглядаємо стилі, як особливі системні ефекти («відгуки») особистості у відповідь на різні типи управлінських ситуацій, а з іншої сторони, як особливі інтегративні управлінські вміння. Такий підхід відкриває можливість сумісного вивчення різних стилів управлінської поведінки (при вимірюванні їх як ймовірності використання) в цілісній системі психологічної культури менеджера.
За результатами вивчення спеціальної літератури ми дійшли до висновку про можливість використання в емпіричному дослідженні таких класифікацій стильових різновидів поведінки керівників. Стиль управління: авторитарний, демократичний, ліберальний, адміністративно-ліберальний, авторитарнодеспотичний, демагогічно-авторитарний, ліберально-авторитарний, демократичноавторитарний, ліберально-демократичний. Стиль керівництва, що випливає 3 особливостей використання часу: орієнтація на виконання задач і досягнення успіху, орієнтація на лідерство, домінування і прийняття рішень, орієнтація на імпульсивність і енергійність, орієнтація на теплі доброзичливі міжособистісні відносини, орієнтація на теоретичний і структурний підхід, орієнтація на зміни та придбання нового досвіду, орієнтація на наслідування, агресивно-захисна орієнтація, орієнтація на реалістичний чи ідеалістичний стилі. Стилі i позиції в діловому спілкуванні: орієнтація на результат, на відношення, на процес; м’який або жорсткий стиль переговорів, орієнтація на принциповий підхід, прагнення перемогти або знайти баланс інтересів, вичікування, байдужість. Стиль лідерства: лідер-організатор, лідер-реорганізатор, лідер-ініціатор, лідерерудит, лідер-генератор, лідер-умілець, лідеремоційного тяжіння, лідер-надихаючий, лідервиконавець, універсальний лідер, ситуативний лідер. Стилі участі в дискусії: ініціація діяльності, пошук інформації, збір думок і погля- 
дів, представлення інформації, вислів думок, доопрацювання, координування, узагальнення, заохочення, забезпечення участі, встановлення критеріїв, вираження почуттів групи; інтегратор, аналітик, системний аналітик; футуролог, історик, синхроніст; оптиміст, песиміст, реаліст; критик, захисник, суддя. Стиль взаємодії: ухилення, згладжування, примусу, компромісу, співробітництва. Стилі вирішення конфліктів: підтримка статус-кво, зневага до протиріч, домінування, апеляція до встановлених «правил гри», компроміс, взаємні уступки, уступка опоненту, надихання опонента, співробітництво. Стиль розвитку організації: новатор, опортуніст, консультант, співучасник, державний діяч, адміністратор, здатний надати імпульс.

Багаторазове повторення управлінських ситуацій стереотипізує стиль і робить менеджера передбачуваним. 3 тієї ж причини стилі з різних ситуацій поєднуються в загальний індивідуальний стиль. Одне 3 сучасних уявлень про ідеальний стиль управління визначає найкращім непередбачуваний стиль як такий, що тримає співробітників у постійному стані робочої напруги перед непередбачуваністю керівника.

\section{Висновки:}

Отже, система психологічних вмінь менеджера сфери культури та дозвілля - це інтегрована, цілісна особистісна конфігурація навичок реальної поведінки, яка включає на змістовному рівні, як мінімум, чотири категорії: психологічні технології взаємодій (ділове спілкування, вміння впливати, педагогічні вміння, публічний виступ); психологічні технології роботи з групами (формування груп, керування відносинами, вирішення конфліктів); внутрішні психологічні технології (особиста ефективність, вміння керувати собою, особиста етика); інтелектуальні та інформаційні психологічні технології (процес мислення і робота 3 інформацією).

В системному розумінні система психологічних вмінь менеджера сфери культури це інтегративний стиль, що поєднує стереотипізовані вибори стилів в окремих типах управлінських ситуацій. Категорії управлінських навичок та їх компоненти знаходяться в системній взаємодії, а конкретні дії менеджерів - $€$ системним ефектом взаємодії вмінь в даний момент.

Дійсною проблемою формування психологічної культури менеджерів сфери культури та дозвілля є проблема розробки і впровадження системних тренінгових психологічних технологій 3 розвитку управлінських вмінь.

Значною проблемою формування конкретних вмінь $\epsilon$ те, що внаслідок особливостей типового навчального процесу ріст навичок зупиняється на першому ж рівні шкали рівня розвитку уміння - інтелектуальному ознайомлені, що спочатку не усвідомлюється, а потім викликає розчарування навчанням. Дійсна майстерність потребує великої кількості по- 
вторень, що в межах учбового процесу забезпечує тільки тренінг. Тобто, фактична проблема формування психологічної культури, як методична так і організаційна, - у відсутності в навчальному процесі повномасштабних системних тренінгів. Необхідно визнати, що існуючі моделі навчання 3 домінуванням лекцій, семінарів і навіть практикумів, в дійсності породжують управлінський дилетантизм, обмежуючи вміння на найнижчому рівні за шкалою майстерності - на рівні інформаційного ознайомлення.

\section{Перспектива подальших досліджень.}

Подальша логіка теоретичних міркувань веде до ствердження існування тотальної внутрішньої взаємодії та взаємовпливу професійнозначущих управлінських вмінь та навичок і пошуку їх зв'язків, системоутворюючих факторів, які можуть швидко максимізувати цільовий компонент - підвищити реальну управлінську ефективність менеджерів сфери культури та дозвілля. Лише на основі розв'язання цього питання можлива розробка науково-обгрунтованих і конструктивних процедур підготовки, відбору менеджерів, їх атестації та професійного навчання.

\section{Перелік використаних джерел:}

1. Бобахо В. А., Левикова С. И. Культурология: Программа базового курса, хрестоматия, словарь терминов./ В.А. Бобахо, С.И. Левикова - М.: ФАИР-ПРЕСС, 2000. $-400 \mathrm{c}$.

2. Измайлова M. А. Психология рекламной деятельно- сти : учеб. для студ. вузов, обучающихся по спец. «Реклама» / М. А. Измайлова. - 3-е изд. - Москва : Дашков и Ко, 2014. - 443 с. : ил., табл.

3. Карамушка Л. М. Психологія управління закладами середньої освіти: Монографія / Л. М. Карамушка. - К.: Ніка-Центр, 2000. - 332 с.

4. Коломінський Н. Л. Психологія менеджменту в освіті (соціально-психологічний аспект). - К.:МАУП, 2000. $286 \mathrm{c}$.

5. Kom Г. М. Психологічна підготовка майбутніх менеджерів до професійної діяльності / Г.М.Кот // Вісник НАУ. Серія: Педагогіка. Психологія: Зб.наук.праць. К.: НАУ, 2009. - Випуск 2. - С.76-81.

6. Kom B. Г. Психологічні умови професійної самореалізації працівників сфери рекламного бізнесу: дис. ... канд. психол. наук : 19.00.07 / Кот Валерія Геннадіївна. - ДВНЗ «Університет менеджменту освіти» АПН України. - Київ, 2018. - 152 с.

7. Лозниия $B$.C. Психологія менеджменту: навчальний посібник./ В.С. Лозниця . - К.:КНЕУ, 1997. - 248 с.

8. Мельников В. М., Ямпольский Л. Т. Введение в экспериментальную психологию личности. / В.М Мельников , Л.Т Ямпольский - М., 1985. - 319 с.

9. Мескон М. Х., Альберт М., Хедоури Ф. Основы менеджмента./ М.Х Мескон, М. Альберт, Ф Хедоури - М., 1993. --702 c.

10. Практикум по психологи менеджмента и профессиональной деятельности: / Под ред. Г. С. Никифорова, М.А Дмитриевой, В. М.Снеткова. - СПб.: Речь, $2001 .-441$.

\section{References (Transliteration):}

1. Bobaxo V. A., Levykova S.Y. Kulturologyya: Programma bazovogo kursa, xrestomatyya, slovar termynov./ V.A. Bobaxo, S.Y. Levykova - M.: FAYR-PRESS, 2000. $400 \mathrm{~s}$.

2. Yzmajlova M. A. Psychologyya reklamnoj deyatelnosty : ucheb. dlya stud. vuzov, obuchayushhychsya po specz. «Reklama»/ M. A. Y`zmajlova. - 3-e izd. - Moskva : 
Dashkov y Ko, 2014. - 443 s. : y’1., tabl.

3. Karamushka L. M. Psychologiya upravlinnya zakladamy serednoyi osvity: Monografiya / L. M. Karamushka. - K.: Nika-Centr, 2000. - 332 s.

4. Kolominskyj N. L. Psy`xologiya menedzhmentu v osviti (social`no-psy`xologichny`j aspekt). - K.:MAUP, 2000. $286 \mathrm{~s}$.

5. Kot G. M. Psy`xologichna pidgotovka majbutnix menedzheriv do profesijnoyi diyal'nosti / G.M.Kot // Visny`k NAU. Seriya: Pedagogika. Psy`xologiya: Zb.nauk.pracz`. - K.: NAU, 2009. - Vy`pusk 2. - S.76-81.

6. Kot $V$. G. Psy`xologichni umovy` profesijnoyi samorealizaciyi pracivny`kiv sfery` reklamnogo biznesu: dy`s. ... kand. psy`xol. nauk : 19.00.07 / Kot Valeriya Gennadiyivna. - DVNZ «Universy`tet menedzhmentu osvity`» APN Ukrayiny`. - Ky`yiv, 2018. - 152 s.

7. Lozny`cya $V$. S. Psy`xologiya menedzhmentu: navchal`ny`j posibny`k./ V.S. Lozny`cya . - K.:KNEU, 1997. - $248 \mathrm{~s}$.

8. Melnykov V. M., Yampol’sky`j L.T. Vvedeny`e v ekspery`mental’nuyu psy`xology`yu ly`chnosty`. / V.M Mel`ny`kov , L.T Yampol`sky`j- M., 1985. - 319 s.

9. Meskon M. X., Al’bert M., Xedoury` F. Osnovы menedzhmenta./ M.X Meskon, M. Al`bert, F Xedoury` M., 1993.--702 s.

10. Praktykum po psy`xology' menedzhmenta y' professy`onal'noj deyatel'nosty`: / Pod red. G. S. Ny`ky`forova, M.A Dmy`try`evoj, V. M.Snetkova. - SPb.: Rech`, 2001. -441.

\section{Kot Galyna}

Ph. D. Psychological Sciences, associated professor of Department of psychology of Kyiv national university of culture and arts, Kyiv (Ukraine)

\section{PSYCHOLOGICAL CULTURE OF FUTURE EVENT MANAGERS: MANAGERIAL SKILLS}

\section{ABSTRACT}

The article is devoted to the system of psychological managerial skills, which helps to maximize the level of managerial efficiency development and formation of the psychological culture of future event managers. The purpose of the article is to construct a space of psychological characteristics of professionally significant skills and, with its help, the development of psychological mechanisms for improving the effectiveness of leadership in the field of culture and leisure.

As a result of the study of literature, judgments about the skills of managers, which on the semantic level (hypothetically) contain the largest psychological component, were selected.

Professionally significant skills and abilities as a psychological factor of effective management implies a higher level of personal skills development, which is manifested at the marginal level of automation of key advertising skills based on the use of psychological knowledge and patterns, and spontaneous adaptability in their practical application and easy situational modification.

Professionally significant skills and abilities are considered as a separate scale for measuring the degree of managerial mastery skills development.

The system of psychological skills of the event manager is an integrative style that combines stereotyped choices of styles in certain types of managerial situations. The categories of managerial skills and their components are in system interaction, and the specific actions of managers - is a systemic effect of the interaction of skills at the moment. 
A significant problem in the formation of specific skills is that due to the characteristics of the typical learning process, the growth of skills stops at the first level of the scale of the level of development of skills - intellectual acquainted, that initially not realized, and then causes disappointment studies. The real skill requires a large number of repetitions, which within the educational process provides only training. That is, the actual problem of the formation of psychological culture, both methodical and organizational - in the absence of a learning process of full-scale system trainings. It is necessary to admit that existing models of teaching with prevailing of lectures, seminars and even workshops actually generate managerial dilettantism, limiting skills at the lowest level in the scale of skill - at the level of information acquaintance.

The real problem of forming the psychological culture of the event managers is the problem of developing and implementing systematic training psychological technologies for the development of managerial skills.

Key words: psychological culture, managerial skills, future event managers, managerial efficiency.

\section{Кот Галина}

Кандидат психологических наук, дочент, доиент кафедры психологии Киевского национального университета культуры и искусств, г. Киев (Украина)

\section{ПСИХОЛОГИЧЕСКАЯ КУЛЬТУРА БУДУЩИХ МЕНЕДЖЕРОВ СФЕРЫ ДОСУГА: УПРАВЛЕНЧЕСКИЕ НАВЫКИ}

Аннотация. Статья посвящена системе психологических управленческих умений, которые способствуют максимизации уровня развития менеджерской эффективности и формированию психологической культуры будущих менеджеров сфери культуры и развлечений. Система психологических управленческих умений - это интегрированная, целостная личностная конфигурация навыков реального поведения менеджера сферы культури и развлечений. Конструирование пространства психологических характеристик профессионально-значимых умений и навыков и с его помощью разработка психологических механизмов повышения эффективности управления сферой развлечений, что, в свою очередь, способствует формированию психологической культуры будущих менеджеров.

По результатам изучения литературы были отобраны суждения об умениях менеджеров, которые на семантическом уровне (гипотетически) содержат наибольшую психологическую компоненту.

Профессионально-значимые умения и навыки как психологический фактор эффективного управления предполагает высокий 
уровень развития личностного мастерства, что проявляется в предельном уровне автоматизированности ключевых умений, основанных на использовании психологических знаний и закономерностей, и спонтанной адаптивности в их практическом применении, и легкой ситуативной модификации.

Профессионально-значимые умения и навыки рассматриваются как отдельная шкала для измерения степени развития управленческого мастерства менеджера.

Система психологических умений менеджера сферы культуры и развлечений - это интегративный стиль, сочетающий стереотипизированные выборы стилей в отдельных типах управленческих ситуаций. Категории управленческих навыков и их компоненты находятся в системном взаимодействии, а конкретные действия менеджеров являются системным эффектом взаимодействия умений в данный момент.

Значительной проблемой формирования конкретных умений является то, что в силу особенностей типичного учебного процесса рост навыков останавливается на первом же уровне развития умения - интеллектуальном ознакомлении, что сначала не осознается, а затем вызывает разочарование обучением. Истинное мастерство требует большого количества повторений, что в пределах учебного процесса обеспечивает только тренинг, то есть, фактическая проблема формирования психологической культуры, как методическая так и организационная, - в отсутствии в учебном процессе полномасштабных системных тренингов. Необходимо признать, что существующие модели обучения с доминированием лекций, семинаров и даже практикумов, в действительности порождают управленческий дилетантизм, ограничивая умения на низком уровне мастерства - на уровне информационного ознакомления.

Действительной проблемой формирования психологической культуры менеджеров сферы культуры и развлечений является проблема разработки и внедрения системных тренинговых психологических технологий по развитию управленческих умений.

Ключевые слова: психологическая культура, управленческие умения, будущие менеджеры сферы культуры и развлечений, управленческая эффективность.

Дата отримання статті: 03.05.2018 Дата рекомендації до друку: 07.05.2018 Дата оприлюднення: 29.05.2018 